China Perspectives

2009/4 | 2009

Religious Reconfigurations in the People's Republic of China

\title{
Rural Women, Old Age, and Temple Work
}

A Case from Northwestern Sichuan

\section{Xiaofei Kang}

\section{OpenEdition \\ Journals}

Édition électronique

URL : http://journals.openedition.org/chinaperspectives/4922

DOI : 10.4000/chinaperspectives.4922

ISSN : 1996-4617

Éditeur

Centre d'étude français sur la Chine contemporaine

Édition imprimée

Date de publication : 31 décembre 2009

ISSN : 2070-3449

\section{Référence électronique}

Xiaofei Kang, «Rural Women, Old Age, and Temple Work », China Perspectives [En ligne], 2009/4 | 2009, mis en ligne le 01 décembre 2012, consulté le 28 octobre 2019. URL : http://journals.openedition.org/ chinaperspectives/4922 ; DOI : 10.4000/chinaperspectives.4922 
[

\section{Rural Women, Old Age, and}

\section{Temple Work}

A Case from Northwestern sichuan

KANG XIAOFEI

This article examines the interface of religion, gender, and old age in contemporary China through the case of a group of rural Han elder women and their community temple in northwestern Sichuan. Without access to monastic resources and charismatic leadership, the women have made the temple a gendered ritual space of their own to obtain social company, spiritual comfort, and moral capital for themselves and their families. Neither victims of feudal superstition nor obstacles to modernisation, they are a dynamic transformative force in contemporary rural China.

A ny visitor to China today cannot fail to notice the massive presence of elder women in local temple activities, but scholarly writings as well as Chinese central and local state agencies have paid little attention to the crucial role of these women in China's post-Mao religious revitalisation. ${ }^{(1)}$ This article brings these women to the fore by studying a group of Han Chinese elder women and a neighbourhood temple they have revived in Songpan, a rural town that has prospered through tourism in the ethnic borderlands of northwestern Sichuan since the 1990s. Drawing on textual materials and ethnographic work in Songpan over four summers $(2003,2004,2005$, and 2007), the article examines the interfaces of religion, gender, and old age in China's growing market economy. It addresses the following questions: In what ways do these women, many of them illiterate or modestly educated, take advantage of new economic resources to revive a community temple and to dedicate themselves to temple work? To what extent do these women experience and interpret tradition, socialism, and the tourist economy through temple work and temple fairs in the region's multi-ethnic environment? In what ways do temple activities offer a form of old age support outside the existing state and family system in rural China?

The case of Songpan's elder women has to be understood in the larger context of an ongoing process of political and scholarly redefinition of Chinese religion in the service of modernisation on the one hand, and local dynamics of adaptation, accommodation, and self-expression on the other. Compared to the female monastic communities in well-established religious centres, a large number of rural elder women, such as those of Songpan, have no religious expertise of any kind and run small-time temples with little or no access to monastic connections. ${ }^{(2)}$ Such community temples, founded and managed by lay people themselves, were commonplace in imperial times. Since the early twentieth century, however, they have been excluded from the five officially recognised "religions" (Buddhism, Daoism, Islam, Catholicism, and Protestantism) and subject to the modernising Chinese state's campaigns against "superstition." (3)

1. This article is derived from a larger collaborative project on religion, ethnicity, and tourism in Northwestern Sichuan. Research and writing of the article were partially supported by an ACLS fellowship in Spring 2007 and an NEH collaborative research award (with Donald Sutton, summer 2004, 2005, 2007). I am grateful to Jean Debarnardi, Vincent Goossaert, Maria Jaschok, Paul Katz, David Palmer, and Donald Sutton for their helpful comments on different versions of this article. I would also like to thank the $\mathrm{He}$ family, Li Quan, Suolangta, Liu Qirong and all the laopopo at Guanyin tang who offered generous help and hospitality in Songpan.

2. In the Songpan region, most temples are run by local lay people with virtually no pres ence of resident monks and nuns. In southeast China there seem to be much closer connections between lay women's religious practices and Buddhist or Daoist monasteries. See, for example, Kenneth Dean, Lord of the Three in One: The Spread of a Cult in Southeast China, Princeton, Princeton University Press, 1998, pp. 225-6; Brigitte Baptandier, The Lady of Linshui: A Chinese Female Cult, Stanford, Stanford University Press, 2008; Huang Pingying, “'Jiezhu' nianfo fengsu zhi xingbie wenhua chutan: yi Minxi Ninghua Shibi Chenjiacun weili" (A preliminary investigation of gender culture as seen in the "receiving the rosary" rituals as performed in Chenjia village, Shibi town, Ninghua), Minsu quyi, vol. 162, no. 12, 2008, pp. 23-83.

3. Ann Anagnost, "Politics and Magic in Contemporary China," Modern China vol. 13, no 1, 1987, pp. 41-61; Prasenjit Duara, "Knowledge and Power in the Discourse of Modernity: The Campaigns against Popular Religion in Early Twentieth-Century China," The Journal of Asian Studies vol. 50. no. 1, 1991, pp. 67-83; Rebecca Nedostup, "Religion, Superstition and Governing Society in Nationalist China," Columbia University Dissertation, 2001; Vincent Goossaert, "Jindai Zhongguo de guojia yu zongjiao: Zongjiao zhengce yu xueshu dianfan (State and religion in modern China: religious policies and scholarly paradigms)," Zhongyang yanjiuyuan jindaishi yanjiusuo jikan vol. 54, 2006, pp. 169-209; Mayfair Mei-hui Yang, ed., Chinese Religiosities: Afflictions of Modernity and State Formation, Berkeley and Los Angeles, University of California Press, 2008. 
In the last three decades, Chinese academic and political agencies have adopted a rather ambiguous attitude toward the revival of community temples: the old association with "superstition" persists, requiring close state supervision and regulation of temple activities. But they are also reinterpreted as "popular religions" or "popular beliefs" essential to preserving Chinese cultural "traditions." ${ }^{(4)}$ Not incidentally, the same ambivalence has been extended to rural elder women. In official and popular representations, these women's illiteracy is commonly associated with backwardness and poverty, all obstacles to China's modernisation, and instead of practicing "religion," they are regarded as having a great penchant for "superstition." Nonetheless, after 30 years' Maoist rule, their old age also serves as a critical link to the pre-Communist traditions that the post-Mao political and academic agencies seek to restore. ${ }^{(5)}$

The perceived correlation between "superstition" and rural elder women in the discourse of China's modernisation resonates with the age-old Confucian elite bias against women practicing religion outside the physical and moral bounds of family. ${ }^{(6)}$ More importantly, it reflects a general scheme by China's policymakers to prevent religion from intruding into other social realms in which the state once had full control. In the realm of old age care and security, urban and rural elders in China greatly benefited from the collective economy and state-sponsored public health system under Mao. Both systems collapsed during the Reform Era. The postMao state provides little or no social support system for the rural elderly, and care in old age has fallen on the shoulders of individual families. ${ }^{(7)}$ The state has turned to the Confucian tradition of filial piety to emphasise the duties and sacrifices of the young toward their elderly parents. ${ }^{(8)}$ Even though sociological studies on aging in Western and Japanese societies have acknowledged the critical role religion plays in fostering mental health among the elderly and in supplementing state-sponsored social support systems, in China the two realms remain separate. ${ }^{\left({ }^{9}\right)}$ Chinese feminist scholars and government officials all recognise the prominence of elder women in religious activities, but they dismiss religion as a negative outlet of rural elders' spiritual life. New religious societies such as Falun Gong and Zhonggong are popular among urban elder women but have been subject to general intellectual contempt and political suppression. ${ }^{(1)}$ Instead of religion, state agencies advocate secular and "modern" approaches to old age, such as establishing "Senior Recreational Centres" (laonian huodong zhongxin) where the elderly can meet, read books and magazines, play card games or ping-pong, and have dance parties and festive pa- rades. ${ }^{(I I)}$ There is also an ongoing national campaign to promote sex, romance, and re-marriage in later life. ${ }^{(12)}$ All these measures are intended to create a healthy aging environment to save rural elder women from sinking into the trap of "feudal superstition." (13)

State and scholarly efforts to mould popular religion and elderly life seem to have little effect on Songpan women's religious practices. Indeed they lack the charismatic leadership

4. Stephan Feuchtwang et al., "The Politics of Culture or a Contest of Histories: Representations of Chinese Popular Religion," Dialectical Anthropology vol. 16, 1991, pp. 251-272, Daniel L. Overmyer, "From 'Feudal Superstition' to 'Popular Beliefs': New Directions in Mainland Chinese Studies of Chinese Popular Religion," Cahiers d'Extrême-Asie, vol. 12, 2001, pp. 103-26

5. Deborah Davis-Friedmann, Long Lives: Chinese Elderly and the Communist Revolution, Stanford, Stanford University Press, 1991, pp. 6-14.

6. Zhou Yiqun, "The Hearth and the Temple: Mapping Female Religiosity in Late Imperial China, 1550-1900," Late Imperial China vol. 24, no. 2, 2003, pp. 109-55; Vincent Goossaert, "Irrepressible Female Piety: Late Imperial Bans on Women Visiting Temples," Nan Nü: Men, Women and Gender in China, vol. 10, no. 2, 2008, pp. 212-41.

7. Deborah Davis-Friedmann, Long Lives: Chinese Elderly and the Communist Revolution, op. cit:; Yang Shengwan, "Who Takes Care of the Rural Elderly? Analysis of Family Arrangement for Old-Age Security in Rural China." Working Paper Series no. 313, The Hague, The Netherlands, Institute of Social Studies, 2000.

8. Yan Yuxiang, Private Life under Socialism: Love, Intimacy and Family Change in Chinese Village, 1949-1999, Stanford, Stanford University Press, 2003, pp. 162-89; Danyu Wang, "Ritualistic Coresidence and the Weakening of Filial Practice in Rura China," Eric T. Miller, "Filial Daughters, Filial Sons: Comparisons from Rural North China," Hong Zhang, "'Living Alone' and the Rural Elderly: Strategy and Agency in Post-Mao China," all in Charlotte Ikels, (ed.), Filial Piety: Practice and Discourse in Contemporary East Asia, Stanford, Stanford University Press, 2004, pp. 16-52, 63-87.

9. See, among others, Melvin Kimble et al., Aging, Spirituality and Religion: A Handbook vol. 1. Minneapolis, Augsburg Fortress Publishers, 1995, Neal Krause et al., "Religion, Social Support, and Health among the Japanese Elderly," Journal of Health and Social Behavior vol. 40, no. 4, 1999, 405-21, Harold G. Koenig, "The Importance of Religious Community to Older Adults," The Gerontologist, vol. 40, no.1, 2000, pp.112-14.

10. According to a 1998 survey of Falun Gong practitioners in five major Chinese cities, $72.9 \%$ were female, and a 1998 survey of Beijing Falun Gong practitioners shows that $67 \%$ were of over 50 years of age. See David A. Palmer, Qigong Fever: Body, Science and Utopia in China, New York, Columbia University Press, 2007, pp. 257-8. On Qigong in general and Falung Gong in particular as strains of Chinese popular religious practices or "redemptive societies," see David A. Palmer, Qigong Fever: Body, Science and Utopia in China, op. cit., pp. 22-7; and David Ownby, Falun Gong and the Future of China, New York, Oxford University Press, 2008, pp. 23-44

11. Huang Jingyi, "Huang Jingyi tongzhi zai quanguo fulian laoling gongzuo xietiao weiyuanhui disanci quanti huiyi shang de jianghua" (Comrade Huang Jingyi's speech at the Third Plenum of All-China Women's Federation's Coordinating Committee on aging and elder life), 11 March 2004, http://www.women.org.cn/allnews/1402/7.html, accessed 13 March 2009; Chen Hui, "Danyangshi nongcun laonian funü qingkuang diaocha yusikao" (Research and Thoughts on the situation of rural elder women in Danyang), 2005 http://www.jswomen.org.cn/newjs/lanmu/, accessed 13 March 2009; Xu Qin, "Shehui bianqian dui laonian funü ruoshi diwei de yingxiang" (The impact of social changes on the underprivileged status of elder women), http://www.feminist.cn/mos/content/view/ 2407/14554/, 2009, accessed 5 March 2009.

12. Jeanne L. Shea, "Sexual 'Liberation' and the Older Women in Contemporary Mainland China," Modern China, vol. 31, no.1, 2005, pp. 115-47.

13. A quick Google search of "laonian funü he zongjiao huodong" (elder women and religious activities) yields many entries from Chinese central and local government and feminist scholarship websites that contain a similar message: the lack of facilities for senior people's cultural activities is a main cause of elder women's sense of "Ioneliness," and they "have no other means but to turn to religion to seek spiritual relief." See note 11. 
and middle-class resources that could mobilise large-scale charitable movements like the Ciji gongdehui (Buddhist Compassion Relief Foundation) in Taiwan. ${ }^{(14)}$ Nor does the temple generate exclusive circles for women's social resistance or elder leadership of lineages, as one would see in rural southeast China. ${ }^{(15)}$ Nevertheless, community temples such as the one in Songpan, as we shall see, fill an important gap between family and state in providing spiritual and social support for the growing population of Chinese rural elderly.

\section{Religion, tourist economy and Han elder women in an ethnic frontier town}

Songpan is located in the Aba Tibetan and Qiang Autonomous Prefecture in northwestern Sichuan Province, on the eastern edge of the Qinghai-Tibetan Plateau. Seated on the narrow banks of the upper Min River and surrounded by the Min Mountain range, Songpan was a commercial hub and a military post linking China Proper, the Sichuan Basin, and the Qinghai-Tibetan grassland from the Ming to Republican times. ${ }^{(16)}$ By 1949, its inhabitants were still predominantly Tibetan and Qiang, who lived mostly up in the mountains, while Han and Hui Muslim immigrants established military garrison towns and commercial and agricultural settlements along the river valleys. In the town of Songpan itself, which is so small that one can walk from the north to the south gate in about 20 minutes, Hui Muslims lived in the north, and the Han mostly in the south, a residential pattern that has continued into contemporary times.

Up until the 1950s, religious establishments in the Songpan region reflected the ethnic settlement pattern. Tibetan Bon had its strong hold to the north and east of Songpan City. There were about 28 to 32 Bon religious establishments and a smaller number of Tibetan Buddhist monasteries of the dGe-lugs-pa, Sa-skya-pa, and rNying-ma-pa sects. ${ }^{(17)}$ Muslim mosques were also established in the Hui settlements along the rivers. In the northern part of Songpan town there were two mosques, the upper one and lower one, several building blocks apart. Outside the city gate and further northeast was the Northern Mosque and two major Gongbei (Muslim Sufi tombs). Han Chinese temples and shrines dotted the map of Songpan town, ensuring the Chinese cosmological order. The most important landmark was the City God temple (Chenghuang miao) alongside the county government office on the high western hill overlooking the city. Down the slope were the Buddhist Temple of Great Compassion and the
Guanyin Pavilion (Guanyin ge). The Temple of the Fire God (Huoshen miao) and the Temple of the Dragon King (Longwang miao) were located north of the city gate. The Palace of Zhenwu (Zhenwu gong) and the Martial Temple (Wumiao) occupied the very northwestern corner just below the city wall. The Civil Temple (Wenmiao), the Wenchang Palace (Wenchang gong), and the Temple of the Medicine King (Yaowang miao) were in the northern part of the town. South of the Min River was dedicated to the Temple of the Eastern Mount (Dongyue miao) and the Jade Perfected Palace (Yuzhen gong ${ }^{(18)}$ ).

Some of the Han temples were already in decline during Republican times, and almost all of the Han, Hui, and $\mathrm{Ti}_{-}$ betan religious establishments were destroyed during Maoist times. Since the 1980s, two Muslim mosques and a Sufi Gongbei in Songpan town and most of the Tibetan monasteries in the region have been revived. In an effort to restore the "cultural heritage" sites and to pacify potential ethnic disturbances, the local government provided funding to the revival. Han Chinese temples, however, have to rely solely on raising money through individual and family donations, and many are subject to official restrictions on "feudal superstition." Many Han Chinese saw the lack of official funding as an official denigration of their culture and welfare. The resentment has intensified with local government efforts to boost the local economy through tourist development around Jiuzhaigou and Huanglong, two new national scenic parks north of Songpan. ${ }^{(19)}$ Almost every family has a member or two working in a tourism-related industry, and the sources of household income have multiplied. Most jobs in tourism, however, are temporary, and few provide job security. As everywhere else in post-Mao China, there is a pervasive

14. On the global success and women's leadership of the Ciji gongdehui, see Julia C. Huang and Robert Weller, "Merit and Mothering: Women and Social Welfare in Taiwanese Buddhism," Journal of Asian Studies, vol. 57, no. 2, 1998, pp. 379-96; Julia C. Huang, Charisma and Compassion: Cheng Yen and the Buddhist Tzu Chi Movement, Cambridge, MA, Harvard University Press, 2009.

15. Marjorie Topley, "Marriage Resistance in Rural Kwangtung," in Margery Wolf et al., Women in Chinese Society, Stanford, Stanford University Press, 1975, pp. 67-88; Judith Stockard, Daughters of the Canton Delta: Marriage Patterns and Economic Strategies in South China, 1860-1930, Stanford, Stanford University Press, 1989; Pan Hongli, "The Old Folks' Associations and Lineage Revival in Contemporary Villages of Southern Fujian Province," In Tan Chee-Beng, ed., Southern Fujian: Reproduction of Traditions in PostMao China, Hong Kong, Hong Kong University Press, 2006, pp. 69-96.

16. He Yuanqing, Songpan jilue, p. 3b, 1873; Fu Chongju et al., Songpan xianzhi, 1924, j 2 , pp. 39a-b; Songpan xianzhi bianzuan weiyuan hui, Songpan xianzhi, 1999, pp. 1-5.

17. Toni Huber, "Contributions on the Bon religion in A-mdo (1): the Monastic Tradition of Bya-dur dGa'-mal in Shar-khog," Acta Orientalia vol. 59, 1998, p. 182 and note 7.

18. For a complete list of Hui mosques and Han temples and shrines in Songpan town, see Fu Chongju et al., Songpan xianzhi, op. cit., enclosed map of the city and j.5, "miaotan," pp. 1a-10a.

19. Songpan xianzhi bianzuan weiyuan hui, Songpan xianzhi, op. cit., p. 868. 


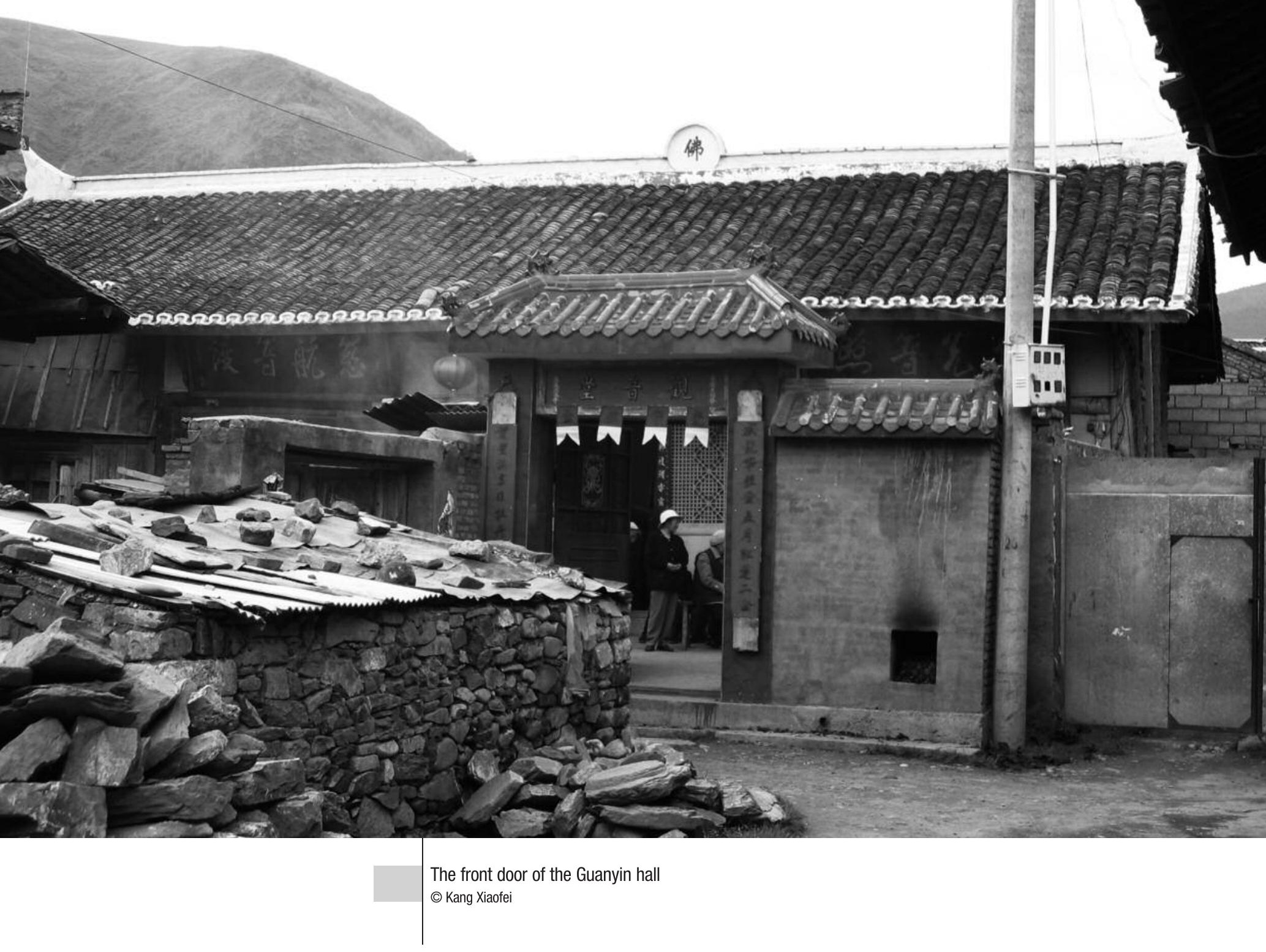

sense of moral decline, rooted in the distrust of the state system and the unpredictable market. Also, as tourist development plays up Tibetan ethnic culture and religion for market profits, many Tibetan villages and monasteries along the tourist highway "have gotten rich first." Han Chinese peasants feel left behind, and some have turned to community temples to restore moral order and to reassert a sense of ethnic pride.

Han elder men participate in the revival of major temples, but visiting temples and doing temple work are perceived mainly as an elder woman's specialty. This is partially due to an implicit gender distinction in local tradition: husbands and wives are not supposed to be seen together in public. Elder men gather at street corners and tea houses, where they can spend the day smoking, chatting, and playing cards or mahjongg. Elder women, on the other hand, meet at temples. When elderly men are asked why they do not go to temples, the most common answer is: "My wife is going," or "that is a matter for 'old ladies' (laopopo)." The few elder men who do temple work usually either work separately from their wives or ask them to stay home to avoid being "laughed at" as a couple. They also proudly distinguish themselves from the illiterate "old ladies" with their ability to read, write, or build things. Many working men and women acknowledge that they are simply too busy to visit temples, but their mothers or mothers-in-law go on their behalf. Some middle-aged women join in temple work after their children have been married and established their own families. Local cadres also maintain a rather patronising attitude toward elder women who have no special religious skills: the women's age entitles them to respect, tolerance, and sympathy, while their illiteracy and therefore "ignorance" make them too "dumb" to cause any serious political troubles.

Official and male bias toward elder women's age, gender, and illiteracy could work to the advantage of these women. Ranging from 50 to 80 years old, these women raised families of multiple children during Maoist times. In the last two decades, as their grown-up children have become the main family wage earners, they have been liberated from family responsibilities. Most live with the families of one of their sons and receive various forms of material support from all of their adult children. They are by no means rich, but they 
are physically active and financially secure, and have plenty of spare time. As they no longer directly contribute to the family coffers, they take up the responsibility of converting material wealth into moral capital on behalf of their adult children. Having passed menopause, and working separately from their male partners, they believe they have the requisite ritual cleanliness for the task.

Three major Han Chinese temples have been revived in Songpan since the 1980s: the City God temple, the Guanyin Pavilion and Guanyin Hall (Guanyin tang). Because of their distinct architectural features, claims of long histories, and prominent locations on the mountain slope, the Guanyin Pavilion and the City God temple attract local visitors as well as tourists. In contrast, the Guanyin Hall, the main object of this study, is anything but notable. It is located less than 100 yards south of the city wall, hidden among the Han-populated farm houses, with its front door facing the pig pens of the house next door and the back door opening onto a narrow alley.

The 20 to 30 elder women who live in a quarter-mile radius of the temple are the sole founders, supporters, and patrons of the temple, and most of them are neighbours and relatives of each other. Anywhere from 50 to 80 local people visit the temple during major temple festivals.

Perhaps because of its inconspicuous location and its members' modest backgrounds, the temple thrives without gaining official registration and tourist attention. Yet, the importance of the temple in local religious life cannot be overlooked. Most Han temples in the Songpan region rely heavily on the support of Songpan's elder population, especially elder women such as those of the Guanyin Hall. In addition to running their own temple, the elder women of the Guanyin Hall also make regular contributions to the two other aforementioned temples. In particular, they help host major temple fairs at the City God temple and go on annual pilgrimages together as one of the most active groups in Songpan's religious life.

\section{Literacy, legitimacy and the space of formal ritual worship}

The Guanyin Hall consists of a front yard, a front hall, a narrow connecting room, and a backroom kitchen, occupying a total of about 3,000 square feet inside and out. The temple is actually a small remnant of the former Temple of the Eastern Mount, surviving the large temple's destruction in the 1960s for conversion into an oil processing house for the local People's Commune. When the communes were abol- ished in the 1980s, the elder women reclaimed the dilapidated building and renovated it into a temple. They run the temple in their own democratic way, electing several administrators by voice vote during temple gatherings: one takes care of food supply and preparation during temple fairs, one oversees temple finance, and the other watches over temple property. Should a new task arise, they elect someone to take responsibility. If the elected one fails to perform her task to their satisfaction, they will yell out someone else's name to replace her in the next gathering.

Despite the temple's small size, its front hall and backroom offer two gender-specific ritual spaces. The front hall and the front yard have a spatial arrangement that links the local territorial gods to the cosmological power of Buddhism: on the two sides of the temple entry are two small territorial shrines, one dedicated to the earth god and his wife, and the other to the nameless souls. The centre of the front hall features Bodhisattva Guanyin and her two female companions. On the left side of Guanyin are the statues of Amida Buddha and his retinue.

The legitimating power of written and bureaucratic language characterises major activities in the front hall. The issue of legitimacy is especially pertinent for a small temple like the Guanyin Hall that has no distinct historical, architectural, or political values to warrant the local government's tolerance. Even though the women worship a wide range of deities and spirits, they insist on identifying themselves as officially recognised Buddhists and on establishing a bureaucratic ritual procedure in order to secure legitimacy. A typical temple fair day in the front hall means scripture chanting throughout the day, culminating in the final submission of a written memorial that is first read aloud and then burned for delivery to the gods. The women understand this procedure of ritual chanting to be just like a "political mass meeting": the invocation is a leader's opening speech, the scriptures are the content of the meeting, and the memorial is the leader's closing speech. Since most elder women are illiterate, the ritual space that revolves around reading and writing is an arena of interaction and negotiation with men and the outside world they represent. Men are customarily hired to do the reading and writ ing required for various temple tasks. In Songpan, men (and very occasionally women) who provide religious service for a fee or sometimes free of charge are called teachers $\left(\right.$ laoshi $\left.{ }^{(20)}\right)$. They usually have no formal clerical training or

20. On the role of religious specialists in local society, see also Vincent Goossaert, "Resident Specialists and Temple Managers in Late Imperial China," Minsu quivi vol. 153, 2006 pp. 25-68; and Adam Chau, "Superstition Specialist Households"?: The Household Idiom in Chinese Religious Practices," Minsu quyi vol.153, 2006, pp. 157-202. 

Two of the elder women working in the kitchen during a temple festival

(c) Kang Xiaofe

ual etiquette: one has to cover one's head in the temple to show respect to the gods; women should not come in when they are not ritually clean (during menstruation); one should not take pictures of gods.

Many women have learned major scriptures by heart over the years. They undertake the role of carrying out and spreading the scriptures' moral messages of filial piety, honesty, and kindness, and denunciation of lust and greed. Two of the most chanted scriptures are the "Precious Penance of Xiangshan" (Xiangshan Baochan) and the "Scripture of the Blood Bowl" (Xuepen jing), both emphasising the popular Buddhist themes of filial piety and women's suffering. ${ }^{(22)}$ In the nearby Guanyin Pavilion, which these women visit often, the front wall features 24 colourful murals depicting the famous "24 tales of filial piety," all featuring filial sons and daughters making prodigious sacrifices for their parents in Chinese history. The elder women believe that the ritual chanting and ritual display of moral messages, plus the monetary donations they make on behalf of their families, will bring good fortunes to their children and grandchildren in an increasingly competitive world. They also strengthen the women's emotional ties with their children and establish intergenerational reciprocity that could enhance their old-age security.

\section{The kitchen and women's work}

If the front hall is where the elder women pay tribute to the power of literacy, then the backroom kitchen is purely a women's realm. The front hall and the back kitchen are connected through a narrow corridor room, where there are several storage boxes containing cooking oil, flours, and ritual paraphernalia, and two beds used by the women to take turns watching over the temple at night. The kitchen itself has two huge stoves, a water sink, some shelves for kitchen utensils, and a working space for ten to 20 people.

Hosting temple festivals is the most important activity for the elder women. ${ }^{(23)}$ The Songpan temple festivals do not have the well-established temple associations and sophisticated multi-party coordination that Adam Chau has documented so well in Shaanbei. Nonetheless, a similar dynamic between hosts and guests prevails in Songpan's temples as well. At the Guanyin Hall and other temples in Songpan run by elder women, it is through cooking in the kitchen and preparing the communal meal for all visitors that the women assume what Chau defines as "sovereignty" over the temple. ${ }^{(24)}$ On the temple festival days, the hired man and guests, mostly middle-aged and elder women from nearby vil-

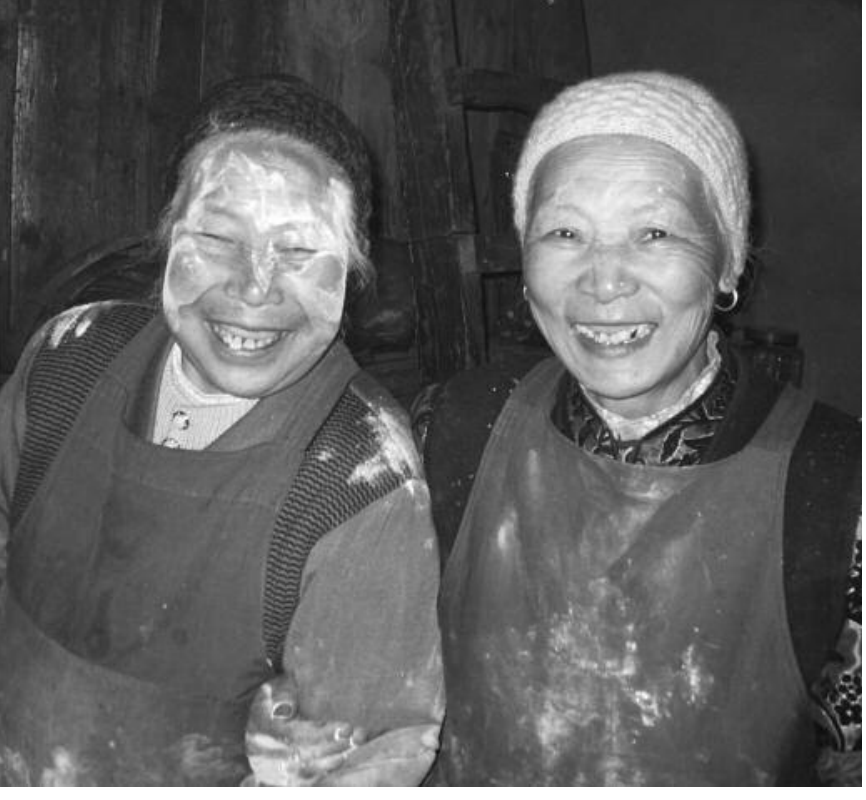

lages and towns, chant scriptures in the front hall. Regular members of the temple work all day in the kitchen. Two meals are served: lunch around 12 p.m. and an elaborate dinner around 5 p.m. The women usually arrive at the temple around 6 a.m. and start the day by lighting incense in the front hall and the fire in the kitchen stoves. During the day, they work on separate tasks: some tend the fire and boil water, some peel potatoes and wash vegetables, and some make buns, noodles, and gelatine (liangfen). They take turns going into the front hall to offer incense and donations, but they return quickly to the kitchen work, serve lunch to every visitor, and then wash dishes and start the second round of cooking. Around 5 pm., they join the final ritual of submit ting the memorial to the gods, and then serve eight dishes to the tables set up in the front hall. At the end of the day, these women stay late, washing, cleaning, putting away leftover food, and extinguishing burning incense and the kitchen fire.

Food and food preparation are important means by which women all over the world construct meaningful religious life. ${ }^{(25)}$ The communal vegetarian meals (zhaifan) have im-

22. On scriptures about the legend of Miaoshan and Bodhisattva Guanyin, see Yu Chünfang Kuan-yin: the Chinese Transformation of Avalokite vara, New York, Columbia University Press, 2001, pp. 293-350. On the theme of filial piety in Chinese Buddhist literature, see Stephen Teiser, The Ghost Festival in Medieval China, Princeton, Princeton University Press, 1996; and Alan Cole, Mothers and Sons in Chinese Buddhism, Stanford, Stanford University Press, 1998.

23. Major festivals of this temple include the three Dragon Flower Assemblies (Longhua hui), honouring the Lamp-Lighting Buddha, Shakyamuni Buddha, and Maitreya Buddha on the fifteenth of the third, fifth, and ninth lunar months respectively, the birthday of Shakyamuni Buddha on the eighth of the fourth lunar month, and the birthday of Bodhisattva Guanyin on the nineteenth of the second, sixth, and ninth lunar months.

24. Adam Chau, Miraculous Response: Doing Popular Religion in Contemporary China, Stanford, Stanford University Press, 2006, pp. 124-46.

25. Caroline W. Bynum, Holy Feast and Holy Fast: The Religious Significance of Food to Medieval Women, Berkeley and Los Angeles, University of California Press, 1987; Susan Sered, Women as Ritual Experts: The Religious Lives of Jewish Elder Women in Jerusalem, New York, Oxford University Press, 1992, pp. 90-102; Li Yu-chen, "Siyuan chufang li de jiemeiqing: zhanhou Taiwan fojiao funü de xinbie yishi yu xiuxing" (Jiemeiqing in the monastic kitchen in post-war Taiwan: the gender identity and community solidarity of Buddhist women), in Zhongyang yanjiuyuan minzuxue yanjiusuo jikan, vol. 87, 1999, pp. 97-128. 
portant ritual meanings for the women. First, the meals are a major expression of the women's religious piety. It is no small achievement to eat vegetarian in Songpan, since the locals, regardless of their ethnic origin, all believe that meat is a daily necessity to survive the harsh highland environs. For all of them, a meal is not a meal without meat. Only a small number of elder women at the Guanyin Pavilion are "lifelong Buddhist vegetarians" (chi changzhai de), and most of the elder women of the Guanyin Hall and of other local temples are "semi Buddhist vegetarians" (chi huazhai de), meaning that they observe a Buddhist vegetarian diet only for a limited period of time each year. The communal vegetarian meals, therefore, are particularly important occasions for these women to proclaim themselves as good Buddhists. ${ }^{(26)}$

Second, working in the kitchen is a strenuous effort to gain religious merit. Not all women serve with equal diligence. I observed that some women, especially the mother of a highlevel county official and a woman whose son runs a successful construction company, sat there chatting and rarely worked. The economic and political gap among these women may have an impact on the division of labour in temple activities, yet for those who work hard, everybody is equal in serving Bodhisattva Guanyin, and they are just as capable, if not more, in gaining moral capital with their hard work. As one woman responded to another woman's complaint about those who sat there all day without lifting a finger: "The bodhisattva watches from above, and the bodhisattva knows."

Third, through serving and sharing the communal meal, the elder women expect both material and symbolic returns from gods and the larger community. "Merit money" (gongde gian) from temple fairs is an important source of temple income. When consuming a communal meal, all temple guests are expected to donate money (shuai gongde) to guarantee blessings from the gods and to help the temple sustain itself. The eight-dish dinner is meant to be offered first to Bodhisattva Guanyin through a ritual performed on behalf of all temple members. Only after Guanyin's acceptance of the offering is assured can the people sit and start to eat. The leftovers from the meals and altar offerings are distributed evenly among all members of the temple who worked in the kitchen. These women then bring their share home to their family members. The meals transform the women's kitchen work into religious offerings in the front hall. Through consuming the food, the women transform the offerings into Guanyin's blessings on themselves and their family members.

\section{The temple as a social space}

Research into later life has shown that in addition to family care, social support and social integration are critical for healthy aging. Elder people rely on social support systems to establish a sense of personal belonging, engagement with the outside world, and positive contributions to others. ${ }^{(27)} \mathrm{In}$ Songpan, temple gatherings are major occasions for elder women to consolidate ties with their female kin and friends outside home. Take the example of a local woman, Grandma $\mathrm{He}$, who works diligently on all temple fair days. In ordinary times, she also comes to the temple simply to "shua," meaning to "hang out" or to "have fun." At the temple she joins her two sisters, who are both widowed but have had very different lives. One married a local cadre, and their adult children have taken up important government positions. The other married a peasant, and her three adult children are peasants and odd-job workers. Grandma $\mathrm{He}$ also meets two next-door neighbours here. One is a woman in her 60 s whose husband and son run a family blacksmithing business. The other is in her late 50 s and is the daughter of Grandma He's brother-in-law. Other regulars at the temple are also long-time local residents whom Grandma He knows well. While in the temple Grandma $\mathrm{He}$ and these women chat, tease, and exchange news with each other while doing all kinds of temple work. Their conversation topics range widely, from a newborn baby at so-and-so's house to how much the pigs they have raised will weigh by the time of the next Lunar New Year. The temple is always full of laughter and noise. Grandma He may not love every single member of this group, and interpersonal tensions and conflict are frequent, but navigating through the intricate relationships in this small network of sisterhood gives women such as Grandma $\mathrm{He}$ a sense of belonging, security, and solidarity. Contrary to official rhetoric that places religion in opposition to science, reason, technology, and modernity, the elder women find themselves at ease with both religious traditions and China's modernisation. They live in two times: going along with the official Gregorian calendar so that family gatherings happen regularly on weekends and public holidays, but also closely following the Chinese lunar calendar that punctuates their lives with year-round temple fair days at their own temples and at other temples in the region (see

26. Vegetarianism is an important component of monastic Buddhism in China, but it is not required in Tibet, India, and many other parts of the world. Among Chinese lay Buddhists, some are lifelong vegetarians and some are "semi-vegetarians." See John Kieschnick, "Buddhist Vegetarianism in China," in Roel Sterckx, (ed.), Of Tripod and Palate: Food Politics and Religion in Traditional China, New York, Palgrave, 2005, p. 186 
below). Their calendrical knowledge, in addition to the periodic vegetarianism they have adopted, secures their status as the ritual representatives of their families. They also have a strong sense of making their religious practices an integral part of the modern state rather than being "backward" or "superstitious." Alongside Bodhisattva Guanyin the women have placed a new framed photo of Zhao Puchu (19072000), the head of China's Buddhist Association from 1980 until his death in 2000 (Deng Xiaoping is another popular object of worship in local temples). They also post big-character posters on the temple walls, such as "Love the Country, Love the Religion" and "Denounce Feudal Superstitions; Fortune-telling and Spirit Possession Are Illegal!" Such official slogans may be posted mainly for the temple's self-legitimisation and self-protection, but by the same token, many elder women also try hard to be good Buddhists by willingly denouncing officially defined "superstitions."

The temple is also an important venue for the elder women to integrate their everyday experiences into the ongoing changes of Chinese society. The topic of a new cable service fee, for example, recurred for several days at the temple. In early 2005, the county government commercialised the cable service and began to charge a subscription fee to every household. Many elder women coming to the temple complained about the change. Some used a political argument, saying that those who could not afford the fee would miss CCTV's seven o'clock evening news - the source of the party-state's voice on major current affairs. Others lamented the newly risen power of money: "Nowadays everybody is into making money, even the government." As the market economy has penetrated state propaganda machines, the discussions at the temple help the women digest and adapt themselves to these changes.

Thanks to the surplus income from the tourist economy, many women have become tourists themselves and come to the temple to share their tourist experiences. What impresses them most is urban life, modern technologies, and commercial development. The topic that raises the most interest is visiting Mao's Memorial Hall in Beijing's Tiananmen Square. Seeing Mao's remains in person gave these women a sense of fulfilment through the power of the market. But Mao has also become a nostalgic symbol of their youth, which is remembered as an egalitarian time free of all the vices brought by the market economy. The women's changing religious devotion during and after the Mao era are best embodied in their heightened attention to Mao's remains, when they vie to ask "How does it look?" and "Has it decayed?" For them, Mao's mummified body is truly a stunning technological feat beyond their comprehension. But just as worship of spirits and dead souls is an important part of their everyday religious rituals, Mao's corporeal presence is also a religious wonder that eternalises his godly power in these women's minds. Through temple gatherings the women channel their complex feelings about the socialist past and the present.

\section{"Tibetan or Han, we all believe in Buddha"}

The elder women's temple activities also respond to Songpan's multi-ethnic environment. Songpan was on the margins of both Chinese and Tibetan central states until the 1950s, and it was geographically remote until the 1980s. It has a long history of local ethnic conflicts, yet its various ethnic groups also see themselves as different from all outsiders, either the Tibetans from central Tibet or the Han beyond the mountains. Since the 1980s, competition for tourist resources has intensified pre-existing ethnic tensions, but the increasing importance of tourism also highlights the physical, linguistic, and cultural differences between "Songpan natives" (Songpan ren) and outside tourists. ${ }^{(28)}$

The Han Chinese identity of the elder women is derived from their daily encounters with and regular sharing of ritual festivals with their ethnic neighbours. They are open to nonHan practices, as is evident in the furnishings of the temple itself. In the front hall, the elder women have raised a gigantic wheel of scripture that extends from the floor all the way to the roof. Buddhist images and scriptures are pasted on all sides of the wheel. This is an obvious copy of the scripture wheels typical of Tibetan Bon monasteries. The Tibetan belief that turning the wheel once equals reciting the scriptures on the wheel once must have special appeal to the illiterate Han Chinese women. The borrowing of Tibetan practices, however, does not prevent Han women from emphasising ethnic differences. Many explicitly express which ritual forms are Han and which are Tibetan, especially in the ritual use of food: whereas yak butter and barley are essential elements in Tibetan offerings, Han Chinese use only veg-

27. Neal Krause et al., "Religion, Social Support, and Health among the Japanese Elderly," art. cit., Harold G. Koenig, "The Importance of Religious Community to Older Adults," art. cit., Iris Chi, et al., Elderly Chinese in Pacific Rim Countries, Hong Kong, Hong Kong University Press, 2001.

28. On how tourist development intensified competition for religious resources among different ethnic groups in Songpan, see Xiaofei Kang, "Two Temples, Three Religions, and a Tourist Attraction: Contesting Sacred Space on China's Ethnic Frontier," Modern China vol. 35, no. 3, 2009, pp. 227-255; Donald Sutton and Xiaofei Kang, "Making Tourists and Remaking Locals: Religion, Ethnicity, and Patriotism on Display in Northern Sichuan," in Tim Oakes et al. Religion on Display, forthcoming. 
etable oil on temple altars and in temple cooking. The offerings to gods have to be local Han food too: steamed "longevity peaches" (peach-shaped buns), stir-fried and pickled vegetables, and gelatine. Such ethnic differences are extended to the offerings to the dead as well: Han Chinese offer buns and fruits, and Tibetans offer tsampa made of a mix of cooked barley flour, yak butter, and tea. They are not to be confused.

The Han elder women's alternate experiences of ethnic distinctions and common Songpan identity are played out in the regional network of temple fair systems. Han Chinese temples and Tibetan monasteries hold multiple temple festivals throughout the year and often draw large multi-ethnic crowds. The women of the Guanyin Hall see their temple as a small unit of such a large regional network. They help host some temple festivals close to home, such as those of the City God temple, but know well that hosting is only one part of the social etiquette of exchange. ${ }^{(29)}$ Their religious calendar is also marked by visiting festivals of other Han temples and Tibetan monasteries, including the Lady Baima (Baima niangniang) Festival on the sixth of the sixth lunar month in Gaotunzi, a village several miles north of Songpan, the Guanyin Temple Fair on the nineteenth of the sixth month in Zhanglang, an old garrison town 12 miles northeast of Songpan city, the Tibetan festivals held at the Ga'mal monastery on the seventeenth of the first and fifth month, and the Ring-spung monastery festival on the seventeenth of the fourth month. They are good guests in Han Chinese temples, chanting scriptures, making monetary donations, and consuming meals served by the women of the host temples. When going to Tibetan temple fairs, they act more as onlookers for the "renao" atmosphere: they usually bring their own food and pay homage to gods; some join $\mathrm{Ti}$ betan crowds to circumambulate monasteries and sacred mountains.

The regional temple festivals culminate on the fifteenth of the sixth month every year, when local Tibetans and Han Chinese and to a lesser degree Qiang all go on pilgrimage to Huanglong (or Sertsuo in Tibetan), a sacred mountain 40 miles northeast of Songpan city. The women of Guanyin Hall are a notable presence at the annual pilgrimage. Here Tibetans and Han Chinese share the sacred sites, but worship different objects, Tibetans the mountain god of Shar dung ri, and Han Chinese the Yellow Dragon Perfected Man at the Temple of the Yellow Dragon. ${ }^{(30)}$ The line between host and guest is erased, with each pilgrim group bringing or cooking their own food in and outside the temple. Some Tibetans follow Han elder women's practice of throwing flowers in a mountain-top water pool, and telling fortunes and praying for fertility as the flowers turn and twirl. The elder women and other Han pilgrims follow the Tibetan practice of throwing rlung-ta - small square paper prints for good fortune - at high places. Through the process of hosting, visiting, and sharing temple fairs, the elder women construct a holistic view of a multi-ethnic world that has little to do with the conquering power of $\mathrm{Han} \mathrm{Chi}-$ nese culture or the ethnic unity promoted in official rhetoric. They establish Buddhism, not the totalitarian party-state, as a common ground on which they recognise ethnic differences yet freely borrow, integrate, and perform various ritual forms of their Tibetan neighbours. It is based on this holistic view of a Buddhist temple network that they recognise ethnic differences between Han and Tibetan on the one hand, and identify themselves with fellow Tibetans as Songpan people on the other. As many Han Chinese women frequently summarise it, "Tibetan or Han, we all believe in Buddha, and we are all Buddhists." (31)

\section{Conclusion}

The case of Songpan provides some historical insights into women, old age, and religion in China. Elder women have always played prominent roles in Chinese popular religious traditions. Much current research on gender and Chinese religion contrasts the procreative power of women and the motherly and grandmotherly goddesses that represent ideal womanhood free of female pollution. ${ }^{(32)}$ A new focus on how these goddesses might have mirrored the images and inspired the religious activities of rural elder women would complement and even revise the familiar picture of filial piety in traditional and modern Chinese family life. Moreover, it would open up new windows to examine gender and

29. Major fairs at the City God temple include the Festival of the Goddesses of the Three Heavens (Sanxiao niangniang) on the third of the third lunar month, The City God's birthday on the twenty-first of the third month, the Middle Primordial (Zhongyuan) Festival on the fifteenth of the seventh month, and the Festival of Winter Clothing Delivery on the first of the tenth month. Because of limited space, I will discuss the women's role and Tibetan presence in these fairs in future articles.

30. The pilgrimage to Huanglong/Sertsuo is the main subject of study in the collaborative book by Donald Sutton and me.

31. Tibetans make similar comments, but with different twists, emphasising the importance of Tibetan religious elements.

32. Emily M. Ahern, "The Power and Pollution of Chinese Women," in Margery Wolf et al., Women in Chinese Society, Stanford, Stanford University Press, 1975, pp. 193-214; P. Steven Sangren, "Female Gender in Chinese Religious Symbols: Kuan Yin, Matsu, and the 'Eternal Mother,"' in Signs vol. 9, no. 4, 1983, pp. 4-25; Kenneth Pomeranz, "Power, Gender, and Pluralism in the Cult of the Goddess of Taishan," in Theodore Huters, et al., Culture and State in Chinese History: Conventions, Accommodations, and Critiques, Stanford, Stanford University Press, 1997, pp. 182-206; Brigitte Baptandier, The Lady of Linshui, op. cit. 
religious power and the impact of such power on female religiosity, elderly life, and the symbolic representations of elder women in the discourses of civilisation and modernisation.

Songpan women's religious activities also resonate with elder women's lives in other cultures. It has been discovered as a common pattern in many patriarchal societies that women's power and status grow as they age, and "women's work" is a great resource for women to move freely between the public and domestic spheres and to adapt better to old age than elder men. ${ }^{(33)}$ The Han elder women's temple activities share much in common with those in the Senior Citizens' Center in California and in Jerusalem, both of which provide an important social space for Jewish elder women of Eastern European and Kurdish origins to become ritual masters through everyday activities of cooking, story-telling, and preparing for religious holidays and through different interpretations of established rituals. ${ }^{(34)}$

Still, what distinguishes the Songpan elder women from those of other historical periods and other cultures is how they have successfully carved out a space of their own under the post-Mao Chinese state's reformulation of gender, religion, and old age care. It is hard for Chinese state agencies to come to terms with the link between the post-Mao religious revival and social support for the elderly, because such a link poses a fundamental challenge to the modern nationstate's legitimacy and moral authority. For state agencies and the intellectual elite, the leisure time, financial resources, and mental health of China's elderly remain an arena of contestation between religion and modernisation. The statesponsored modern facilities, such as the Senior Recreational Centres, have little appeal to the rural elderly, especially to women, who consider card games and sports more of men's domain and whose illiteracy prevents them from reading as a pastime. They may sing and dance at temple festivals, but they shy away from singing in Mandarin or dancing in public.

It is through the community temples that rural elder women turn their perceived weaknesses - their illiteracy, their modest social background, and their old age - into advantages to seek spiritual comfort, social company, and a ritual place to serve, instead of being served by, their families and their communities. Such a ritual space provides an alternative source of moral authority in rural society that competes with the state's discourse of old age and modernity. Whereas the state promotes filial piety as both a moral and legal responsibility of adult children for their aging parents, the rural elder women frame it as a religious merit reciprocated to them through their temple work and monetary donations. Despite official and scholarly efforts to use "modernisation" to "rescue" rural elder women from "superstitions," community temples, shrines, churches, and other kinds of local religious facilities remain a favourite space in which rural elder women can best experience and act upon agency. Neither victims of feudal superstition nor obstacles to modernisation, they are a dynamic transformative force in contemporary rural China. •

\section{Glossary}

Baima niangniang 白馬娘娘 Chenghuang miao 城隍廟

chi changzhai de 吃長齋的 chi huazhai de 吃花齋的

Dongyue miao 東岳廟 Falunggong 法輪功

Gongbei 拱北 Gongde qian 功德錢 Guanyin ge 觀音閣

Guanyin tang 觀音堂 Huanglong 黄龍 Huoshen miao 火神廟

Jingfang 經方 Jiuzhaigou 九寨溝

laonian huodong zhongxin 老年活動中心

Laopopo 老婆婆 laoshi 老師 liangfen 涼粉

Longhuahui 龍華會 longpiao 龍票 Longwang miao 龍王廟

Sanxiao niangniang 三霄娘娘 Shua 要 shuai gongde 危功德

Songpan ren 松潘人 Songpan 松潘 wangsheng 往生

Wenmiao 文廟 Wenchang gong 文昌宫 Wumiao 武廟

Xiangshan baochan 香山寶懺 Xuepenjing 血盆經

Yaowang miao 藥王廟 Yuzhen gong 玉真宫

zhaifan 齋飯 Zhenwu gong 真武宫 Zhonggong 中功

Zhongyuan 中元
33. David Gutmann, Reclaimed Powers: Toward a New Psychology of Men and Women in Later Life, New York, Basic, 1987; Barbara G. Myerhoff, "Bobbes and Zeydes: Old and New Roles for Elderly Jews," in idem., Remembered Lives: The Work of Ritual, Storytelling, and Growing Old, Ann Arbor, The University of Michigan Press, 1992, pp. 191-227.

34. Barbara G. Myerhoff, Number our Days, New York, Dutton, 1980, Susan Sered, Women as Ritual Experts, op. cit. 